\title{
UDC 629.4.027.31-272.82
}

\author{
O. H. REIDEMEISTER ${ }^{1 *}$, A. V. KIVISHEVA ${ }^{2 *}$ \\ ${ }^{1 *}$ Dep. «Car and Car Facilities», Dnipropetrovsk National University of Railway Transport named after Academician \\ V. Lazaryan, Lazaryan St., 2, Dnipropetrovsk, Ukraine, 49010, tel. +38 (056) 37315 19, e-mail reidemeister@mail.ru, \\ ORCID 0000-0001-7490-7180 \\ ${ }^{2 *}$ Dep. «Car and Car Facilities», Dnipropetrovsk National University of Railway Transport named after Academician \\ V. Lazaryan, Lazaryan St., 2, Dnipropetrovsk, Ukraine, 49010, tel. +38 (056) 37315 19, e-mail nastaci@yahoo.com, \\ ORCID 0000-0001-8811-7243
}

\section{DEPENDENCE OF AIR SPRING PARAMETERS ON THROTTLE RESISTANCE}

Purpose. In this paper it is necessary to conduct: 1) research and analyse the influence of throttle element pneumatic resistance on elastic and damping parameters of air spring; 2) to obtain the dependence of air spring parameters on throttle element pneumatic resistance value. Methodology. The work presents the elaborated model of the air spring as a dynamic system with three phase coordinates (cylinder pressure, auxiliary reservoir pressure, cylinder air mass). Stiffness and viscosity coefficients were determined on the basis of system response to harmonic kinematic disturbance. The data for the analysis are obtained by changing the capacity of the connecting element and the law of pressure variation between the reservoir and the cylinder. The viscosity coefficient is regarded as the viscosity ratio of the hydraulic damper, which for one oscillation cycle consumes the same energy as the air spring. The process of air condition change inside the cylinder (reservoir) is considered to be adiabatic; the mass air flow through the connecting element depends on the pressure difference. Findings. We obtained the curves for spring viscosity and stiffness coefficients dependence on the throttle resistance at three different laws, linking airflow through the cylinder with the pressure difference in cylinder and reservoir. At both maximum and minimum limiting resistance values the spring viscosity tends to zero, reaching its peak in the mean resistance values. Stiffness increases monotonically with increasing resistance, tends to the limit corresponding to the absence of an auxiliary reservoir (at high resistance) and the increase in cylinder volume by the reservoir volume (at low resistance). Originality. The designed scheme allows determining the optimal parameters of elastic and damping properties of the pneumatic system as function of the throttle element air resistance. Practical value. The ability to predict the parameters of elastic and damping properties of the pneumatic system as function of the throttle element air resistance will improve the running performance of carriages, the comfort of passenger transportation and reduce the wear of the rolling stock and the track caused by interaction of carriage and rails.

Keywords: spring suspension; air spring; viscosity coefficient; stiffness coefficient

\section{Introduction}

Air springs are the most progressive elastic elements of running gear, which are used in passenger car bogies. Their main advantage is the ability to maintain the position of the body at a certain level relative to the rail heads, regardless of the load, due to automatic adjustment of air pressure within the spring $[4,6,7]$. Furthermore, they have good noise and vibration reduction properties, providing comfort of passengers $[9,12,16]$.

Ability to take up high horizontal and diagonal displacements as well as the torsional strength make the air suspension systems an attractive solution for use on all bogies $[1,4,7]$.

There are several types of air spring systems [4, $8,10,14]$ (air damper and air spring with one or two extra reservoirs) and it is convenient to de- scribe their dynamic properties with the help of the mechanical equivalent model.

To date, the most common for use on passenger cars is a pneumatic system design, consisting of an air spring and an auxiliary reservoir. The reservoir is needed to reduce the vertical stiffness $[4,7,13]$. As an auxiliary reservoir the internal cavity of the bogie frame truss is used; besides the auxiliary reservoirs may be located in the car body or in the space under the body.

As a rule, the air springs are limited by size according to the condition of their location on the bogie frame, so they are separated from auxiliary reservoirs and communicate with the latter by connecting pipes. The pipes are equipped with connecting elements, which have a calibrated vent holes. When overflowing from the cylinder into the 
auxiliary reservoir the air has to overcome an air resistance of the connecting element, causing the spring to get the damping characteristics along with the elastic ones.

\section{Purpose}

The purpose of this work is to research and analyse the influence of throttle element pneumatic resistance on elastic and damping parameters of air spring. To obtain the dependence of air spring parameters on throttle element pneumatic resistance value.

The changes in the connecting element flow capacity largely affect the overall pneumatic system. For the analysis of the newly constructed or improved existing air suspension system the issue of the connecting element capacity, along with the capacity of the auxiliary reservoir and the air spring casing, is an extremely important parameter.

\section{Methodology}

To analyse the dependence of elastic and damping properties of air suspension system (hereinafter - the spring) on the connecting element parameters we consider the spring (Fig. 1) comprising the following components: rubber-cord casing cylinder (1), reservoir (4), piping (3) and connecting element (2).

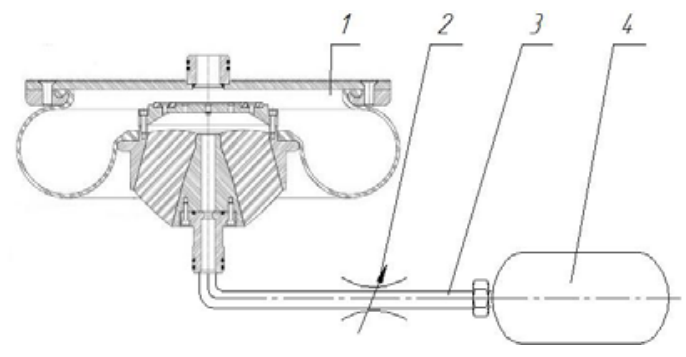

Fig. 1. Diagram of air spring with reservoir

The spring is considered as a dynamic system with three phase coordinates (cylinder pressure, auxiliary reservoir pressure, cylinder air mass). The process of air condition change inside the cylinder (reservoir) is adiabatic; the mass air flow through the connecting element depends on the difference of cylinder and reservoir pressure. [15].

The spring has the following parameters: cylinder volume $V 1$ and reservoir volume $V 2$, support surface area $\mathrm{S}$ (we assume that it is independent of cambering of spring), air mass $m$. The total pressure in cylinder and reservoir is denoted by $p 1$ and $p 2$, respectively. They differ from the excessive one by the atmospheric pressure value $p_{\mathrm{a}}$.

The set of equations describing the system operation is as follows:

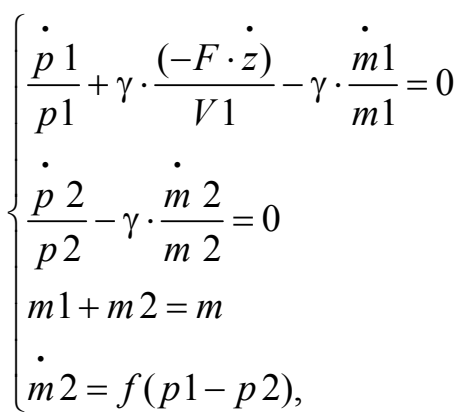

where $z$ - cambering of spring; $m 1$ - air cylinder mass; $m 2$ - reservoir air mass; $\gamma$ - polytropic exponent; $f$ - function defining the mass air flow through the connecting element.

We assume that the spring operation proceeds at the ambient temperature equal to $\mathrm{t}=25^{\circ} \mathrm{C}$ and the pressure equal to $p_{\mathrm{a}}=1$ atm.

Equations (1) are interdependent, which allows approximate representation of the air spring as the elastic element with stiffness $C$ and the viscous friction element with viscosity $\beta$ (Fig. 2) mounted in parallel [5].

Let us consider cinematic excitation of this system, when its deformation is described by the expression $z=a \cdot \sin 2 \pi f(a-$ body oscillation amplitude, $f$-disturbing frequency).

The maximum strength occurs when $z=a$ (the signs are not significant), it is equal to:

$$
p_{\max }=C \cdot a,
$$

and the work done by an external power source per full oscillation cycle -to the viscous friction element operation, i.e.

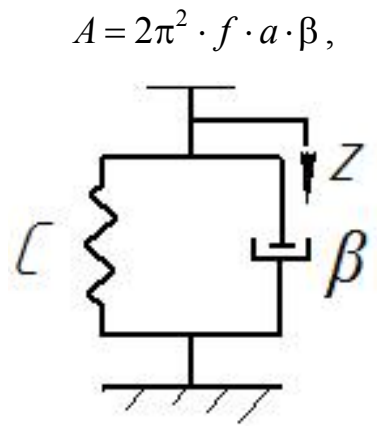

Fig. 2. The equivalent mechanical system 
Expressions (2) and (3) are used for determining the equivalent stiffness and viscosity of the air spring. For this purpose we integrate the equation (1) when $z=a \cdot \sin 2 \pi f$, which will allow determining the spring overpressure $p 1$ as a function of time $t$. The force exerted by the external source on the spring supporting surface is equal to:

$$
p=\left(p 1-p_{\mathrm{a}}\right) \cdot S,
$$

and the work of this force per oscillation period is equal to:

$$
A=\int p d z=2 \pi f \int_{0}^{t} \cos 2 \pi f t \cdot p(t) d t
$$

Having determined $p_{\max }=\max _{t} p(t)$ and $A$, we find the equivalent coefficients:

$$
\begin{gathered}
C=p_{\max } / a, \\
\beta=A / 2 \cdot \pi^{2} \cdot f \cdot a^{2} .
\end{gathered}
$$

The research is carried out at a variable amplitude of oscillations ( $a=0.005 \mathrm{~m}, a=0.010 \mathrm{~m}, a=$ $0.020 \mathrm{~m}$ ).

Taking into account the dependence of changes in gas (liquid) flow value on the section resistance and the vessel pressure employed in the fluid dynamics $[2,11,14]$, we choose the dependence of pressure difference changes $\sqrt{(p 1-p 2)}$, but for the research completeness and based on various types of connecting elements, we do not neglect the following dependencies: $(p 1-p 2)$, $(p 1-p 2)^{2}$

Calculations are carried out with different flow capacity of the connecting element: from virtually open connecting element, which equalizes the cylinder and reservoir pressure, to almost completely closed one, which shuts off the cylinder from the reservoir [3].

Under these assumptions, we determine the dependence of cylinder overpressure $p 1$ on time $t$. The obtained data on pressures allow drawing the conclusions about the work done by the system, its equivalent coefficients of stiffness and viscosity under various operating conditions.

\section{Findings}

We obtained the curves for three laws of pressure variation of air suspension stiffness and viscosity characteristics, as well as determined the system operation depending on the connecting element flow capacity (Fig. 3-5.):

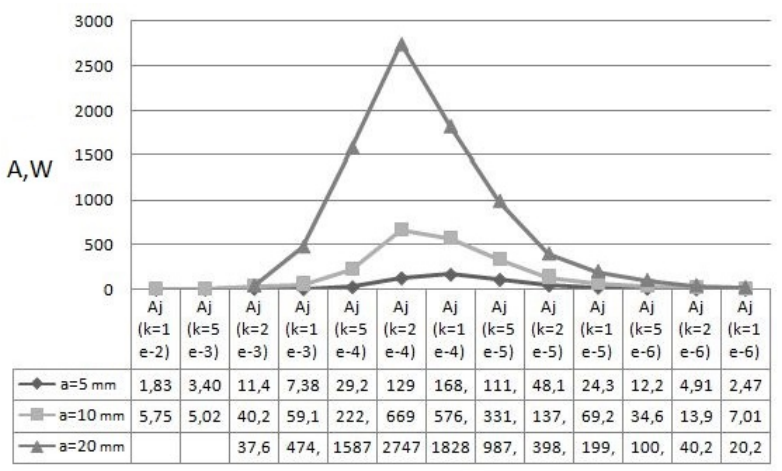

Fig. 3. Dependence of system operation on element pneumatic resistance when $\sqrt{(p 1-p 2)}$

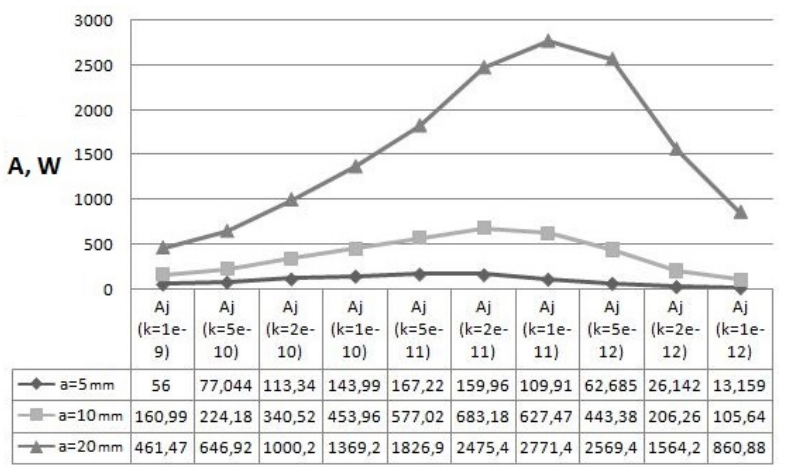

Fig. 4. Dependence of system operation on element pneumatic resistance when $(p 1-p 2)$

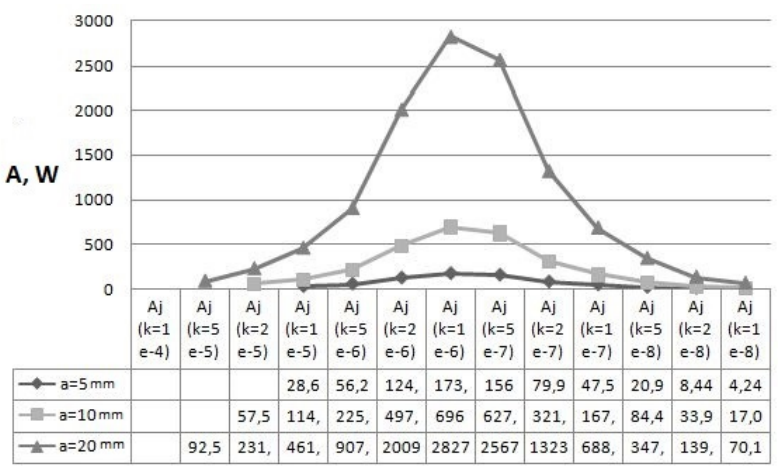

Fig. 5. Dependence of system operation on element pneumatic resistance when

$$
(p 1-p 2)^{2}
$$


As can be seen from the above curves, the system indicates the lowest peak value of the work performed in case of pressure difference change curves $\sqrt{(p 1-p 2)}$. Likewise in case of the curve $\sqrt{(p 1-p 2)}$ the maximum system performance level is achieved at the beginning of the opening cycle of the connecting element, that allows achieving the system peak performance for a shorter period of time than that of systems with pressure change dependences $(p 1-p 2),(p 1-p 2)^{2}$

It is also natural that the maximum work performed by the system falls to the oscillation amplitude of $0.020 \mathrm{~m}$, whereas when the oscillation amplitude is $0.0050 \mathrm{~m}$, the changes in the system operation in case of decreased flow capacity of the connecting element are insignificant.

Analyzing the formula (3), it can be concluded that the more work that the system makes, the higher the pressure needs to be maintained in the cylinder for its high-quality work, which in turn can lead to complication in spring supply system. However, the fundamental parameters for spring operation are stiffness and viscosity, not its work. Therefore, it is advisable to analyze these figures for all three dependences of pressure change.

For the above-mentioned law of the spring support surface motion, the phase shift between $p 1$ and $z$ is virtually absent, which makes it possible to estimate the stiffness spring by the formula (4). Whereas the equivalent viscosity coefficient is determined as the viscosity coefficient of the hydraulic damper, which absorbs per one oscillation cycle the same energy as the air spring by the formula (5).

We obtain the following curves of spring stiffness and viscosity coefficient dependence on the parameters characterizing the pneumatic resistance of the element that connects the cylinder with the auxiliary reservoir (Fig. 6-11):

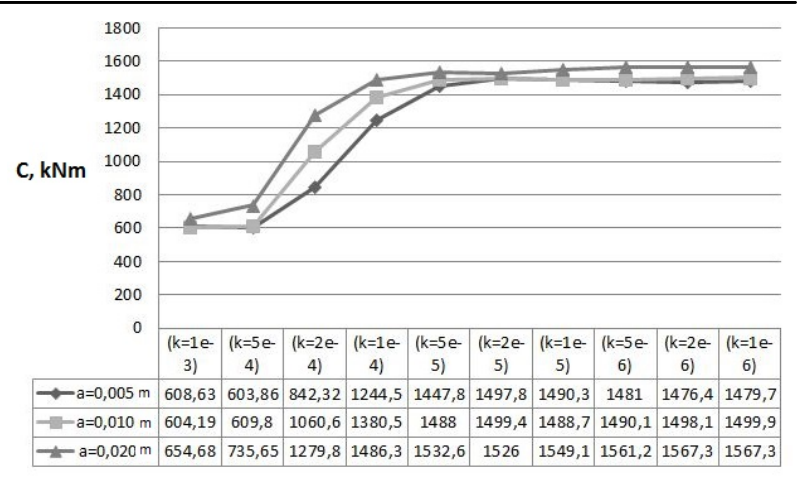

Fig. 6. Curve of stiffness coefficient dependence on the parameters characterizing the element pneumatic resistance where $\sqrt{(p 1-p 2)}$

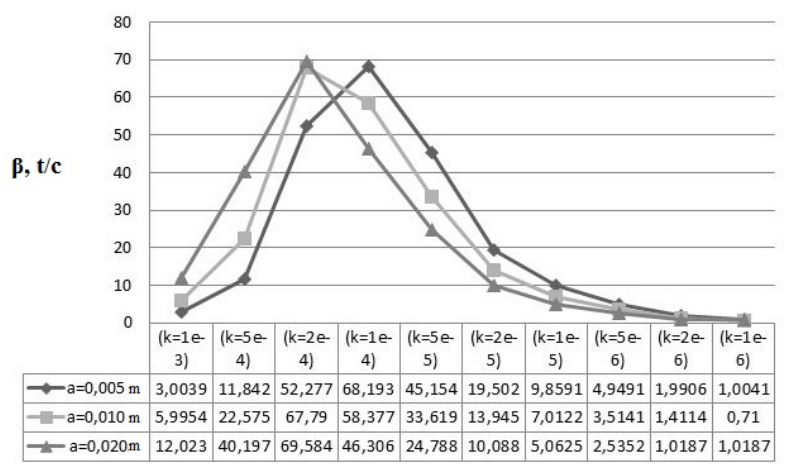

Fig. 7. Curve for viscosity coefficient dependence on the parameters characterizing the element pneumatic resistance where $\sqrt{(p 1-p 2)}$

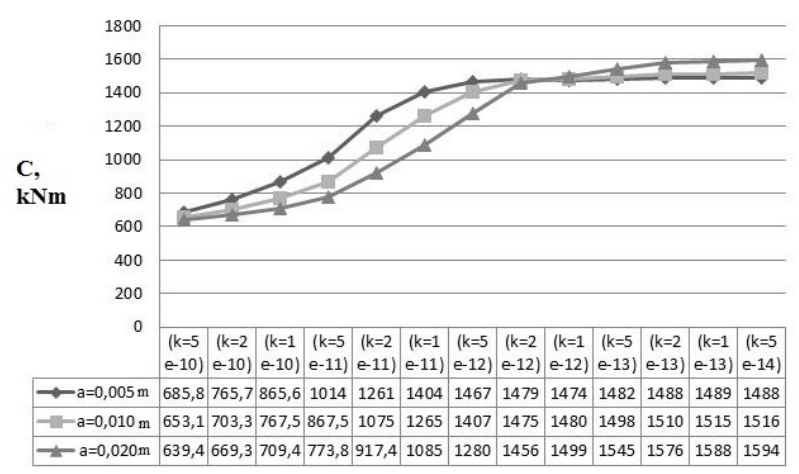

Fig. 8. Curve of stiffness coefficient dependence on the parameters characterizing the element pneumatic resistance where $(p 1-p 2)^{2}$ 


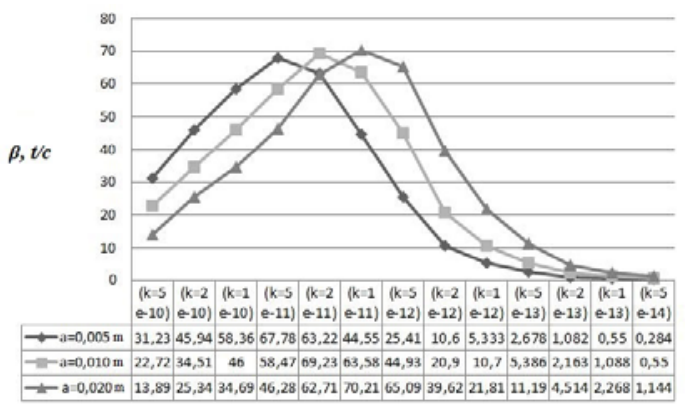

Fig. 9. Curve for viscosity coefficient dependence on the parameters characterizing the element pneumatic resistance where $(p 1-p 2)^{2}$

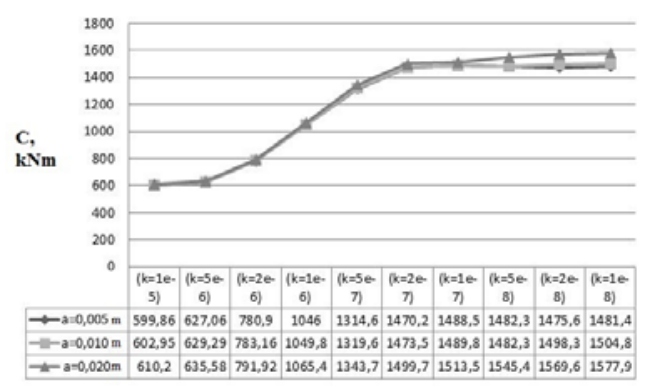

Fig. 10. Curve of stiffness coefficient dependence on the parameters characterizing the element pneumatic resistance where $(p 1-p 2)$

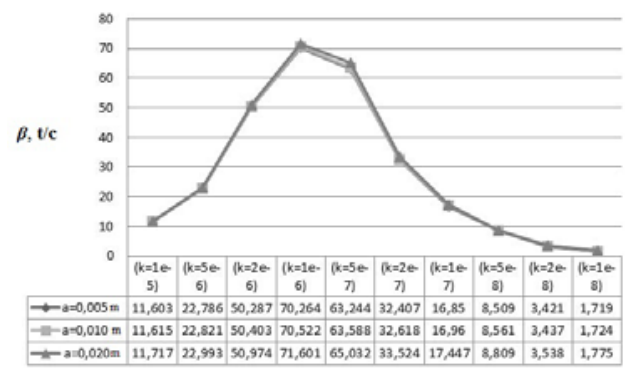

Fig. 11. Curve for viscosity coefficient dependence on the parameters characterizing the element pneumatic resistance where $(p 1-p 2)$

By increasing the viscosity coefficient, the system smooth operation and, consequently, the level of passenger comfort is improved. The curves show that early achievement of maximum viscosity is observed for $\sqrt{(p 1-p 2)}$ however, this figure

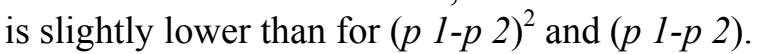

\section{Originality and practical value}

The designed scheme allows determining the optimal parameters of elastic and damping properties of the pneumatic system as function of the connecting element air resistance. The practical value is that the ability to predict the parameters of elastic and damping properties of the pneumatic system as function of the throttle element air resistance will improve the running performance of carriages, the comfort of passenger transportation and reduce the wear of the rolling stock and the track caused by interaction of carriage and rails.

\section{Conclusions}

Analysing the above curves, it can be concluded that the system stiffness coefficient increases significantly with increased resistance created by the connecting element, herewith the system viscosity tends to zero, which adversely affects the damping of the system. In its turn, the system viscosity is the highest at the mean resistance value of the flow generated by the connecting element. Moreover, the system reaches the maximum viscosity at the mean value of the stiffness coefficient that proves the beneficial effect on the system damping quality of the presence of the element with variable pneumatic resistance, which connects the cylinder with the auxiliary reservoir.

\section{LIST OF REFERENCE LINKS}

1. Басов, Г. Г. Теоретичні й експериментальні дослідження екіпажної частини тепловозів : навч. посібник / Г. Г. Басов, В. І. Нестеренко. Луганськ : Ноулідж, 2011. - 247 с.

2. Войткова, Т. Г. Основы гидравлики : учеб. пособие / Т. Г. Войткова. - Иркутск : ИрГТУ, 2007. -68 c.

3. Голечков, И. Ю. Об алгоритме оптимизации динамических параметров рельсового экипажа / И. Ю. Голечков, О. В. Дружинина, О. Н. Карпеченкова // Информ.-телекомуник. технологии и математ. моделирование высокотехнолог. систем : тез. докладов Всерос. конф. с междунар. участием. - Москва, 2012. C. 258-260.

4. Горобец, В. Л. Улучшение динамических характеристик тягового подвижного состава с использованием управления гашением энергии колебаний / В. Л. Горобец, Н. П. Снитко, А. Д. Лашко // Вісн. Дніпропетр. нац. ун-ту залізн. трансп ім. акад. В. Лазаряна. - Дніпропетровськ, 2011. - Вип. 36. - С. 7-15.

5. Ибраев, Б. М. Параметры пневматического рессорного подвешивания рельсового автобуса для казахстанской железной дороги : автореф. дис .... канд. техн. наук : 05.22.07 / Ибраев 
Бейбит Максутович ; Моск. гос. ун-т путей сообщения. - Москва , 2009. - 24 с.

6. Камаев, В. А. Оптимизация параметров ходовых частей железнодорожного подвижного состава / В. А. Камаев. - Москва : Машиностроение, 1980. -215 с

7. Макаренко, Ю. В. Результаты исследования системы пневматического рессорного подвешивания транспортного средства с микропроцессорным направлением / Ю. В. Макаренко, В. Н. Балев, В. Г. Маслиев // Вестн. нац. техн. ун-та «ХПИ». - Харьков, 2001. - № 18. С. $70-83$.

8. Мелихов, А. Н. Эффективная система демпфирования пневморессоры скоростного подвижного состава : автореф. дис. ... канд. техн. наук : 05.22.07 / Мелихов Александр Николаевич ; Моск. государств. ун-т путей сообщ. - Москва, 1994. - 22 c.

9. Механическая часть тягового подвижного состава : учеб. для вузов ж. -д. трансп. / И. Б. Бирюков, А. Н. Савойськин, Г. П. Бурчак [и др.] ; под ред. И. В. Бирюкова. - Москва : Транспорт, 1992. - 440 с.

10. Создание отечественных пассажирских вагонов на тележках с пневматическим подвешиванием / И. В. Приходько, В. Н. Дузик, С. В. Лутонин [и др.] // Развитие науч. шк. транспорт. механики : тез. междунар. науч.техн. конф. (5.12.2013) / Мин-во образования и науки Украины // Днепропетр. нац. ун-т ж.-д. трансп. им. акад. В. Лазаряна. - Днепропетровск : ДНУЖТ, 2013. - С. 40-45.

11. Чухарева, Н. В. Расчет простых и сложных газопроводов / Н. В. Чухарева. - Томск : Издво Томск. политехн. ун-та, 2010. - 13 с.

12. Iwnicki, S. Handbook of Railway Vehicle Dynamics / S. Iwnicki. - New York : Taylor \& Francis Group, 2006. - 527 p. doi: 10.1201/9781420004892.

13. Modeling of the three-dimensional flow of polymer melt in a convergent channel of rectangular cross-section / K. B. Koshelev, G. V. Pyshnograi, M. Yu. Tolstykh // Fluid Dynamics. - 2015. - Vol. 50. - Iss. 3. - P 315-321. doi: $10.1134 / \mathrm{s} 0015462815030011$.

14. Presthrus, M. Derevation of air spring model parameters for train simulation: Master of Science program [Electronic resource] // M. Presthrus. 2002. - 75 p. - Available at : http://epubl.ltu.se/1402-1617/2002/059/LTU-EX-02059-SE.pdf. Title from the screen. - Accessed : 10.12.2015.

15. Rail applications design guide [Electronic resource] // Firestone Industrial Products Company. - 2005. - 52 p. - Available at: http://www.ekomafirestone.pl/pdf/airail.pdf. - Title from the screen. - Accessed : 10.12.2015.

16. Leichtbau bei Schienfahrzeugen - Bastandsaufnahme und Potenziale / Elek. Bahnen. - 2013. - № 1. - C. 8-12.

\section{О. Г. РЕЙДЕМЕЙСТЕР ${ }^{1^{*}}$, А. В. КІВІШЕВА ${ }^{2^{*}}$}

${ }^{1 *}$ Каф. «Вагони та вагонне господарство», Дніпропетровський національний університет залізничного транспорту імені академіка В. Лазаряна, вул. Лазаряна, 2, Дніпропетровськ, Україна, 49010, тел. +38 (056) 373 15 19, ел. пошта reidemeister@mail.ru, ORCID 0000-0001-7490-7180

${ }^{2 *}$ Каф. «Вагони та вагонне господарство», Дніпропетровський національний університет залізничного транспорту імені академіка В. Лазаряна, вул. Лазаряна, 2, Дніпропетровськ, Україна, 49010, тел. +38 (056) 3731519 , ел. пошта nastaci@yahoo.com, ORCID 0000-0001-8811-7243

\section{ЗАЛЕЖНІСТЬ ВЛАСТИВОСТЕЙ ПНЕВМАТИЧНОЇ РЕСОРИ ВІД ПНЕВМАТИЧНОГО ОПОРУ ДРОСЕЛЯ}

Мета. В науковій роботі необхідно провести: 1) вивчення та аналіз впливу пневматичного опору дросельного елемента на пружні та демпфуючі властивості пневматичної ресори; 2) отримання залежності властивостей пневматичної ресори від величини пневматичного опору дросельного елемента. Методика. Розроблено модель пневматичної ресори як динамічної системи з трьома фазовими координатами (тиск у балоні і додатковому резервуарі, маса повітря в балоні). Коефіцієнти жорсткості та в'язкості визначені по відгуку системи на гармонійні кінематичні обурення. Дані для аналізу отримані шляхом зміни пропускної здатності з’єднувального елемента та закону зміни тисків між резервуаром і балоном. Коефіцієнт в'язкості розглядається як коефіцієнт в'язкості гідравлічного гасителя, який за один цикл коливань поглинає ту ж енергію, що і пневматична ресора. Процес зміни стану повітря всередині балона (резервуара) вважається адіабатичним, масова витрата повітря через сполучний елемент залежить від різниці тисків. Результати. Отримано графічні залежності коефіцієнтів жорсткості та в'язкості ресори від опору дроселя при трьох різних законах, що зв'язують витрати повітря через балон із різницею тисків у балоні та резервуарі. При граничних (як великих, 
так і менших) значеннях опору в’язкість ресори прагне до нуля, досягаючи максимуму в середньому діапазоні величин опору. Жорсткість монотонно зростає при збільшенні опору, прагнучи до меж, відповідним відсутності додаткового резервуару (при великому опорі) і збільшення обсягу балона на обсяг резервуара (при малому опорі). Наукова новизна. Розроблена схема дозволяє виявити оптимальні параметри пружних та демпфуючих властивостей пневматичної системи, залежно від пневматичного опору дросельного елемента. Практична значимість. Можливість прогнозування параметрів пружних та демпфуючих властивостей пневматичної системи, залежно від пневматичного опору дросельного елемента, дозволить поліпшити ходові характеристики вагонів, підвищити комфортабельність перевезення пасажирів, а також знизити знос рухомого складу та рейкової колії внаслідок взаємодії екіпаж-шлях.

Ключові слова: ресорне підвішування; пневматична ресора; коефіцієнт в’язкості; коефіцієнт жорсткості

\title{
А. Г. РЕЙДЕМЕЙСТЕР ${ }^{1^{*}}$ А. В. КИВИШЕВА ${ }^{2 *}$
}

\author{
${ }^{1 *}$ Каф. «Вагоны и вагонное хозяйство», Днепропетровский национальный университет железнодорожного \\ транспорта имени академика В. Лазаряна, ул. Лазаряна, 2, Днепропетровск, Украина, 49010, тел. +38 (056) 3731519 , \\ эл. почта reidemeister@mail.ru, ORCID 0000-0001-7490-7180 \\ $2^{2 *}$ Каф. «Вагоны и вагонное хозяйство», Днепропетровский национальный университет железнодорожного \\ транспорта имени академика В. Лазаряна, ул. Лазаряна, 2, Днепропетровск, Украина, 49010, тел. +38 (056) 3731519 , \\ эл. почта nastaci@yahoo.com, ORCID 0000-0001-8811-7243
}

\section{ЗАВИСИМОСТЬ СВОЙСТВ ПНЕВМАТИЧЕСКОЙ РЕССОРЫ ОТ ПНЕВМАТИЧЕСКОГО СОПРОТИВЛЕНИЯ ДРОССЕЛЯ}

Цель. В научной работе необходимо провести: 1) изучение и анализ влияния пневматического сопротивления дроссельного элемента на упругие и демпфирующие свойства пневматической рессоры; 2) получение зависимости свойств пневматической рессоры от величины пневматического сопротивления дроссельного элемента. Методика. Разработана модель пневматической рессоры как динамической системы с тремя фазовыми координатами (давление в баллоне и дополнительном резервуаре, масса воздуха в баллоне). Коэффициенты жесткости и вязкости определены по отклику системы на гармоническое кинематическое возмущение. Данные для анализа получены путем изменения пропускной способности соединительного элемента и закона изменения давлений между резервуаром и баллоном. Коэффициент вязкости рассматривается как коэффициент вязкости гидравлического гасителя, который за один цикл колебаний поглощает ту же энергию, что и пневматическая рессора. Процесс изменения состояния воздуха внутри баллона (резервуара) считается адиабатическим, массовый расход воздуха через соединительный элемент зависит от разности давлений. Результаты. Получены графические зависимости коэффициентов жесткости и вязкости рессоры от сопротивления дросселя при трех разных законах, связывающих расход воздуха через баллон с разностью давлений в баллоне и резервуаре. При предельных (как больших, так и меньших) значениях сопротивления вязкость рессоры стремится к нулю, достигая максимума в среднем диапазоне величин сопротивления. Жесткость монотонно возрастает при увеличении сопротивления, стремясь к пределам, соответствующим отсутствию дополнительного резервуара (при большом сопротивлении) и увеличению объема баллона на объем резервуара (при малом сопротивлении). Научная новизна. Разработанная схема позволяет выявить оптимальные параметры упругих и демпфирующих свойств пневматической системы в зависимости от пневматического сопротивления дроссельного элемента. Практическая значимость. Возможность прогнозирования параметров упругих и демпфирующих свойств пневматической системы в зависимости от пневматического сопротивления дроссельного элемента позволит улучшить ходовые характеристики вагонов, повысить комфортабельность перевозки пассажиров, а также снизить износ подвижного состава и рельсовой колеи вследствие взаимодействия экипаж-путь.

Ключевые слова: рессорное подвешивание; пневматическая рессора; коэффициент вязкости; коэффициент жесткости

\section{REFERENCES}

1. Basov H.H., Nesterenko V.I. Teoretychni y eksperymentalni doslidzhennia ekipazhnoi chastyny teplovoziv [Theoretical and experimental studies of vehicle-parts for locomotives]. Luhansk, Noulidzh Publ., 2011. 247 p. 2. Voytkova T.G. Osnovy gidravliki [Fundamentals of hydraulics]. Irkutsk, IrGTU Publ., 2007. 68 p. 
3. Golechkov I.Yu., Druzhinina O.V., Karpechenkova O.N. Ob algoritme optimizatsii dinamicheskikh parametrov relsovogo ekipazha [About optimization algorithm of dynamic parameters for rail vehicle]. Tezisy dokladov Vserossiyskoy konferentsii s mezhdunarodnym uchastiyem "Informatsionno-telekomunikativnyye tekhnologii i matematicheskoye modelirovaniye vysokotekhnologicheskikh system» [Abstracts of All Russian Conf. with Intern. Participation «Information and telecommunication technologies and mathematical modeling of hightech systems»]. Moscow, 2012, pp. 258-260.

4. Gorobets V.L., Snitko N.P., Lashko A.D. Uluchsheniye dinamicheskikh kharakteristik tyagovogo podvizhnogo sostava s ispolzovaniyem upravleniya gasheniyem energii kolebaniy [The diagnostic specifications improvement for rolling stock's traction with using of damping control of vibrational energy]. Visnyk Dnipropetrovskoho natsionalnoho universytetu zaliznychnoho transportu imeni akademika V. Lazariana [Bulletin of Dnipropetrovsk National University of Railway Transport named after Academician V. Lazaryan], 2011, issue 36, pp. 7-15.

5. Ibraeyv B.M. Parametry pnevmaticheskogo ressornogo podveshivaniya relsovogo avtobusa dlya kazakhstanskoy zheleznoy dorogi. Avtoreferat. Diss. Kand. [Parameters of pneumatic spring suspension of the rail bus for the Kazakh Railways. Abstract of Cand. Diss.]. Moscow , 2009. 24 p.

6. Kamayev V.A. Optimizatsiya parametrov khodovykh chastey zheleznodorozhnogo podvizhnogo sostava [Optimization of running parts parameters of railway rolling stock]. Moscow, Mashinostroeniye Publ., 1980. $215 \mathrm{p}$.

7. Makarenko Yu.V., Balev V.N., Masliyev V.G. Rezultaty issledovaniya sistemy pnevmaticheskogo ressornogo podveshivaniya transportnogo sredstva s mikroprotsessornym napravleniyem [System research results of the pneumatic spring suspension of a vehicle with microprocessor direction]. Vestnik natsionalnogo tekhnicheskogo universitetata «KhPI» [Bulletin of National Technical university «KhPI»]. 2001, no. 18, pp. 70-83.

8. Melikhov A.N. Effektivnaya sistema dempfirovaniya pnevmoressory skorostnogo podvizhnogo sostava. Avtoreferat. Diss. Kand [An effective damping system of spring-base for rolling stock. Abstract of Cand. Diss.]. Moscow, 1994. 22 p.

9. Biryukov I.B., Savoyskin A.N., Burchak G.P. Mekhanicheskaya chast tyagovogo podvizhnogo sostava [Mechanical part of traction rolling stock]. Moscow, Transport Publ., 1992. 440 p.

10. Prikhodko I.V., Duzik V.N., Lutonin S.V. Sozdaniye otechestvennykh passazhirskikh vagonov na telezhkakh s pnevmaticheskim podveshivaniyem [Creation of domestic passenger cars on air suspension trucks]. Tezisy mezhdunarodnoy nauchno-tekhnicheskoy konferentsii «Razvitiye nauchnoy shkoly transportnoy mekhaniki (5.12.2013)» [Abstarcts of Intern. Sci. and Practical Conf. «Scientific school development of Transport Mechanics»]. Dnepropetrovsk, 2013, pp. 40-45.

11. Chukhareva N.V. Raschet prostykh i slozhnykh gazoprovodov [Calculation of simple and complex gas pipeline]. Tomsk, Tomskiy Politekhnicheskiy Universitet Publ., 2010. 13 p.

12. Iwnicki S. Handbook of Railway Vehicle Dynamics. New York, Taylor \& Francis Group Publ., 2006. 527 p. doi: 10.1201/9781420004892.

13. Koshelev K.B., Pyshnograi G.V., Tolstykh M.Yu. Modeling of the three-dimensional flow of polymer melt in a convergent channel of rectangular cross-section. Fluid Dynamics, 2015, vol. 50, issue 3, pp. 315-321. doi: 10.1134/s0015462815030011.

14. Presthrus M. Derevation of air spring model parameters for train simulation: Master of Science program. 2002. 75 p. Available at: http://epubl.ltu.se/1402-1617/2002/059/LTU-EX-02059-SE.pdf (Accessed 10 December 2015).

15. Rail applications design guide. Firestone Industrial Products Company. 2005. 52 p. Available at: http://www.ekomafirestone.pl/pdf/airail.pdf (Accessed 10 December 2015).

16. Leichtbau bei Schienfahrzeugen - Bastandsaufnahme und Potenziale. Elek. Bahnen, 2013, no. 1, pp. 8-12.

Chief Researcher V. L Horobets, Dr. Sc. (Tech.), (Ukraine); PhD Tech. T. V. Sheleiko (Ukraine) recommended this article to be published

Accessed: Dec. 11, 2015

Received: March 25, 2016 